\title{
Analysis of the Structural Factors of the Party Committee of State-Owned Enterprises to Improving the Leadership Efficiency of the Party Committee
}

\author{
Yingjie Ren*, Lihong Du
}

Xi'an Research Institute of High-Tech, Xi'an, China

*Corresponding author. Email: 359280682@qq.com

\begin{abstract}
This paper analyzed some problems that affected the leadership effectiveness of the Party committee of state-owned enterprises from the structural factors of leadership. It studied the influence of structural foundation, quality structure, age structure, knowledge and professional structure on leadership effectiveness, put forward optimization ideas for common problems of structural factors, and explored new directions for improving leadership effectiveness.
\end{abstract}

Keywords: Leadership effectiveness, Structural foundation, Structural factors.

\section{THE CURRENT SITUATION}

The party committees of state-owned enterprises play a leading role in guiding the direction, managing the overall situation, ensuring implementation, and discussing and deciding major matters of enterprises in accordance with regulations. This has established a position for the leadership of the Party committee of state-owned enterprises in the new era, and at the same time, it has put the burden of the development strategy of state-owned enterprises on the Party committee of enterprises. With the acceleration of technological innovation such as informatization and intelligence, as well as the influx of more diversified values and management concepts, the great test faced by stateowned enterprises puts forward higher requirements for the leadership efficiency of enterprise party committees.

\section{THE RELATIONSHIP BETWEEN THE} LEADERSHIP EFFECTIVENESS OF THE PARTY COMMITTEE OF STATE-OWNED ENTERPRISES AND THE STRUCTURAL FACTORS OF THE LEADING GROUP OF THE PARTY COMMITTEE

\subsection{The Leadership Efficiency of Enterprise Party Committee}

Leadership efficiency generally refers to the leader's behavior ability, working state and work results in the process of implementing leadership, that is, the systematic synthesis of leadership ability to achieve leadership objectives, leadership efficiency and leadership benefits. The Party committee of state-owned enterprises is a leading group, and its leadership efficiency cannot be simply considered as the sum of the leadership effectiveness of the members of the Party committee. It should be a comprehensive embodiment of the leadership, efficiency and effectiveness of leadership after the ability, knowledge and resources mastered by the members of the Party committee are selected according to the dual needs of the party organization and the interests of the enterprise. It consists of: the collective leadership of the Party committee, the leadership objectives to achieve, the efficiency of collective leadership activities, the effectiveness of collective leadership activities and the leadership team itself. The leadership efficiency of the Party committee of state-owned enterprises has the following characteristics:

\subsubsection{Political}

Leading activities must meet the Communist Party's policies and serve the ruling of the Communist Party.

\subsubsection{Comprehensive}

Collective leadership effectiveness is an organic combination of the leadership effectiveness of individual leadership members. 


\subsubsection{Social}

Leading activities can not be separated from the LED group and play a role.

\subsubsection{Historical Inheritance}

Leading members and the previous generation of leading members have a certain inheritance relationship.

\subsubsection{Unity of Subjectivity and Objectivity}

The subjective understanding of the leading team should be consistent with the objective environmental conditions.

\subsubsection{Dynamic Change}

Leadership activities are constantly changing with the situation.

\subsubsection{The Situation is Diverse}

The specific form of leadership effectiveness is not fixed, which is related to the enterprise form.

\subsection{The Influence of Structural Factors on the Leadership Effectiveness of Enterprise Party Committee}

The leading group of the Party committee of stateowned enterprises is composed of 5 to 9 people, generally no more than 11 people. In order to form a qualified collective leadership, on the basis of individual qualification of leading members, it is necessary to match and arrange the quality structure, age structure, knowledge structure and professional structure. [1]

\subsubsection{The Quality Structure Affects the} Rationality of the Division of Labor among the Members of the Party Committee.

Even if the overall quality of leaders is relatively high, there will be differences. The core leading members of the team should meet the quality of grasping direction, principle and policy issues, and should be outstanding in decision-making and personnel selection. The quality of other personnel shall be ensured to meet the work direction assigned to them.

\subsubsection{Age Structure Affects the Overall Style of the Leading Group of the Party Committee}

Older leaders are often experienced and steady in decision-making, but lack of innovation. Younger leadership teams are dynamic and have a strong ability to accept new knowledge, but usually have less power. Members of different ages need to be matched reasonably within the leadership group to lead enterprises to stabilize the situation and promote innovation and development.

\subsubsection{Knowledge Structure and Professional Structure Affect the Decision-making of the Leading Group of the Party Committee}

The leading group must have a high level of knowledge and a professional level of experts. Members should have the ability to study, research, think, express, organize, create, etc. at the same time, some aspects should reach the expert level. Ensure that there will be no major mistakes due to professional blind spots and knowledge blind areas in leadership activities.

From the perspective of structural factors, we should adjust the leading members of the leading group so that they can do their best, bear their own responsibilities, unite and cooperate, and the conflicts can be controlled. In this way, the overall leadership effectiveness of the enterprise party committee can be improved.

\section{THE STRUCTURAL FACTORS INFLUENCING THE LEADERSHIP EFFICIENCY OF THE PARTY COMMITTEE OF STATE-OWNED ENTERPRISES AND THE SOLUTIONS}

The problems existing in the structure of the Party committee of state-owned enterprises should be studied and solved from the influence of individual members and structural factors on the whole leading group.

\subsection{Purify the Members of the Party Committee and Ensure the Reliable Foundation of the Leadership Structure}

The leadership of the Communist Party of China is the most essential feature of socialism with Chinese characteristics, and adhering to the leadership of the party is the highest political principle in contemporary China. The members of the leading group are the basic units that constitute the leadership structure. Members participating in leading activities must guarantee the interests of both the party and the enterprise. For quite some time, the state-owned enterprises only focus on business, not party building, only focus on development, not corruption, leading to corruption among the members of the Party committee. Such members do not meet the requirements of being the foundation of a qualified structure.

Corruption at the level of members of the Party committee is the basis of the leadership structure. The interest demand dominated by the values of problem leaders has deviated from the collective goal. This kind of members play a negative role in the leadership activities, which makes the interests generated by the 
decision-making of the whole senior leadership team shift to their personal interests. Its common means, such as influencing decision-making in the leadership team, giving the organization's interests to related groups for profit, expanding their own power in the evaluation and appointment of subordinates, and influencing the benign competition within enterprises. It is explained by the charismatic leadership theory put forward by Robert house. The members of the Party committee are supposed to have the charisma caused by their special characteristics, which can have a profound emotional impact on the subordinates, make the subordinates follow the leadership of the Party committee, so as to improve the satisfaction and performance of the work and organization. However, due to the collapse of the Party committee's leadership structure, the leadership structure has become loose. This situation is bound to run counter to the needs, beliefs and values of most of the followers in the enterprise, as well as the general environment in which the Communist Party leads the country to better development. The charm of the leading group of the Party committee has declined seriously, leading to the decline of its leadership efficiency. [2]

In order to optimize the leadership structure, it is necessary to purify the basis of the leadership structure. For the corrupt members of the Party committee, they should be removed from the leadership team as soon as possible, and a new leadership structure should be established. According to Zimmer's "trust theory", for the followers of the Party committee, they have full trust in the vision put forward by the Party committee team, providing a reliable guarantee to ensure that all the leadership decisions can be effectively implemented. But corrupt leaders lead to a breakdown of trust between followers and the Party committee. It is obviously difficult to achieve quick results in restoring the one to many trust relationship between the Party committee and its followers. Therefore, the most effective and direct way is to eliminate corrupt members and re form the leading group of the Party committee, so that the followers have a new feeling of the charm of the new Party committee group and establish new trust, so as to lay a foundation for optimizing the leadership structure.

\subsection{Analyze the Structural Factors of the Party Committee and Solve the Problem of Leadership Effectiveness}

Article 33 of Chapter 5 of the party constitution of the 19th National Congress of the CPC clearly stipulates that the party committees (Party groups) of state-owned enterprises play a leading role in guiding the direction, managing the overall situation and ensuring implementation, and discuss and decide major matters of enterprises in accordance with the provisions. In order to ensure the correct direction, complete overall view and effective implementation, it is necessary for a party committee with structural factors to adapt to the times. At present, there are some obsolete problems in the structure of the Party committee of state-owned enterprises, such as quality structure, age structure, knowledge structure and professional structure. It is difficult to realize the way of constructing the leading group directly according to the ideal paradigm in reality. Therefore, the feasible way is to analyze and solve problems from the perspective of leadership factors.

In terms of quality structure, there is a common habit of following the old tradition in the distribution of members of the Party committee. The most common is the work direction before Party A takes over Party B. This approach seems to have worked well for some time in the past. However, as the external situation faced by enterprises is becoming more and more severe and changes faster and faster, this practice of not fully analyzing the new situation and adjusting the work direction and positioning of the members of the Party committee after the change of office will lead to blind areas of tasks and responsibilities after the handover of work direction, and even miss the strategic opportunities for enterprise development. Each adjustment of the members of the Party committee is not only an analysis of the quality of the members, but also an analysis of the new situation faced by the enterprise. We should start from the construction of enterprise party organization and the promotion of enterprise market competitiveness. In terms of organizational construction, in addition to the division of work in accordance with the party's articles of association, we should further analyze the adverse factors that impact the party's organizational construction at this moment, such as the new ideological trend and values outside the enterprise, the influence of major events, etc., because the adjustment of the party's articles of association and regulations has a certain time lag. These real-time factors should be included in the optimization of the quality structure of the Party committee and the division of labor among the members of the Party committee. In terms of competitiveness improvement, in order to find a new growth point in enterprise operation in the leadership activities, we should select qualified members from the Party committee, clarify their responsibilities, carry out demonstration and exploration, and report to the Party committee with data after full investigation, and the Party committee will make decisions. In this way, we can prevent the opportunity of enterprise development from falling into the blind area of division of labor among members of the Party committee.

In terms of age structure, the age of candidates for Party committee members and Discipline Inspection Commission members of domestic central enterprises should generally be able to serve for one term. The party's age is generally no less than five years. The party age of the expert talents in the members of the Party committee of the enterprise can be appropriately 
relaxed, and the party age shall not be less than 3 years. Such provisions can ensure that the leadership of the whole Party committee is rich in experience, but at the same time, it also conveys an incorrect idea that the age and experience of members of the Party committee must be sufficient. Modern physiological science and psychological science show that there is a certain quantitative relationship between one's age and psychological characteristics. The creative impulse of a person is inversely proportional to his age. Young and creative people are mostly in low-level positions, while those who are old and creative are mostly in high positions. Especially in the leading bodies of the Party committee, it is normal that relatively old members are the main members. Such state-owned enterprises are often stable, but lack of strong development momentum. Usually, the most direct way to optimize the age structure of the Party committee is to let young and promising leaders enter the Party committee, and let them directly exert their vitality and creativity to participate in decision-making, so as to change the leadership ability of the whole Party committee. However, this method is difficult to popularize. The leadership of young Party members is often questioned, and only a few of them can enter the Party committee. At this stage, in addition to directly changing the age structure of the Party committee, we can also use the questionnaire survey method to let young non party leaders participate in the major decision-making of state-owned enterprises. First of all, the rudiments of decision-making are put forward by the Party committee. Then, it will be distributed to all levels of leaders, let them analyze the feasibility of decisionmaking from their respective perspectives, and put forward their own views and suggestions for improvement. After the data are collected and analyzed, the data are analyzed and processed again. After the improvement, we should take the leaders who have been accepted as the key object, conduct the investigation again, and reflect the opinions in multiple rounds according to the urgency of decision-making. Finally, although it is the Party committee's team that finalized and implemented the decision, in fact, leaders of all ages have participated in the decision-making, which can alleviate the lack of creativity of the relatively elderly Party committee.

Knowledge structure and professional structure. The overall knowledge level of the Party committee of the state-owned enterprise should belong to the superior level in the level of social intelligence system. The best situation is that in the business scope of the enterprise, the Party committee team as a whole has no knowledge and professional blind spot, and the members of the Party committee have their own strengths in their specialties.However, in the construction of the actual leadership team, it is impossible for the Party committee to be familiar with all the specialties and knowledge inside the enterprise without blind spots. Therefore, it is necessary to ensure that the main specialties are covered, the blind areas of specialties are narrowed and the information channels are unblocked in the process of optimizing the structure of the Party committee. From the perspective of enterprise development and income generation, the expertise and knowledge needed in innovation, production, sales, management and other aspects are those that the Party committee should be familiar with and grasp. These aspects directly affect the competitiveness and even survival ability of enterprises. The enterprise culture, sanitation and greening are the accessories for the improvement of the market competitiveness of the enterprise and the economic benefits, so the Party committee does not need to focus on it for a long time. After grasping the main contradictions, the members of the Party committee should take the way of division of labor and responsibilities, and gradually expand, so as to gradually familiarize the fields that the Party committee team can not grasp in the enterprise. The bottom line is to grasp its development status and ensure that it serves the overall interests of the enterprise. In reality, no matter how the Party committee team optimizes the overall knowledge structure and professional structure, it is rare to be able to be perfectly familiar with the knowledge and professional leadership group required by the whole enterprise, so it is necessary to obtain the intelligence in the blind area of professional knowledge through unimpeded information channels. We should train reliable experts, establish an accurate and timely information processing and transmission mechanism, and provide valuable information for the decisionmaking of the Party committee. The blind area of professional knowledge is certainly small compared with the whole field that can be grasped by the Party committee in the enterprise. However, an extra source of information can further fill in the loopholes that still exist after optimizing the leadership structure.

\section{CONCLUSION}

Purifying the Party committee team and optimizing the structural factors can improve the leadership efficiency of the Party committee of state-owned enterprises.

\section{REFERENCES}

[1] Liping Huang, Jinyuan Jing, On the overall efficiency of the leading group, in: Lanzhou academic journal, 1996, 02, pp. 9-12.

[2] Lin Li, Xiaolin Zuo, Charismatic leadership behavior and its impact on Performance: a literature review, in: Modern trade industry, 2013, 17 , pp. 84-86. 